\title{
AGGUMUlation, ABLATION, AND OXYGEN ISOTOPE VARIATIONS ON THE QUEEN ELIZABETH ISLANDS ICE CAPS, CANADA
}

\author{
By R. M. Koerner \\ (Polar Continental Shelf Project, Department of Energy, Mines and Resources, Ottawa, \\ Ontario $\mathrm{K}_{\mathrm{IA}}$ oE 4 , Canada)
}

\begin{abstract}
Measurements made on traverses over ice caps in the Queen Elizabeth Islands show that there is a region of very high accumulation $\left(>40 \mathrm{~g} \mathrm{~cm}^{-2}\right.$ year $\left.^{-1}\right)$ on the slopes facing Baffin Bay and one of low accumulation ( $<15 \mathrm{~g} \mathrm{~cm}^{\Omega_{2}}$ year $^{-1}$ ) in the interior parts of northern Ellesmere Island. Ablation rates in summer show much less regional variation over the same ice caps except for lower rates along the north-west edge of the islands and possibly on the Baffin Bay slopes as well. However, there is a stronger relationship between ablation and elevation which is exponential below the firn line. From the fractional ${ }^{8} \mathrm{O}$ content of the snow it is shown that Baffin Bay contributes significant amounts of moisture $(>20 \%$ of the total) to the Baffin Bay slopes. In addition the Arctic Ocean is seen as another, but much less significant, moisture source. The $\delta^{18} \mathrm{O}$ data show two effects on the condensation processes-an orographic one (i.e. adiabatic cooling) and a distance-from-source effect (isobaric cooling) where the source is somewhere to the south-east
of the islands.
\end{abstract}

RÉsumé. Accumulation, ablation et variation des teneurs en isotope de l'Oxygène sur les calottes de glace des Illes Reine Elizabeth au Canada. Les mesures réalisées lors de traversées des calottes de glace des Îles Reine Elizabeth montrent qu'il s'agit d'une région de très forte accumulation (plus de $40 \mathrm{~g} \mathrm{~cm}^{-2} \mathrm{a}^{-1}$ ) sur les pentes faisant face à la Baie de Baffin et de faible accumulation (moins de $15 \mathrm{~g} \mathrm{~cm}^{-2} \mathrm{a}^{-1}$ ) dans les parties internes du Nord de l'île d'Ellesmere. Les taux d'ablation estivales ont beaucoup moins de variations régionales sur les mêmes calottes à l'exception de taux plus faibles le long de la cote Nord des îles et peut-être également sur les pentes de la Baie de Baffin. Cependant, il y a une plus forte relation entre l'ablation et l'altitude qui est de forme exponentielle en dessous de la ligne des névés. A partir de la teneur en ${ }^{18} \mathrm{O}$ de la neige, on montre que la Baie de Baffin contribue significativement à l'approvisionnement en eau (plus de $20^{\circ}$ du total) des pentes de la Baie de Baffin. De plus, l'Océan Arctique apparaît comme une autre source d'eau mais beaucoup moins importante. La variation de teneur en ${ }^{18} \mathrm{O}$ met en évidence deux effets sur les processus de condensation: un effet orographique (c'est à dire de refroidissement adiabatique) et un effet de distance à la source (refroidissement isobarique) lorsque la source est quelque part vers le Sud-Est des îles.

Zusammenfassung. Akkumulation, Ablation und Schwankungen des Gehalts an Sauerstoff-Isotopen auf Eiskappen der Queen Elizabeth Islands, Kanada. Messungen bei überquerungen von Eiskappen auf den Queen Elizabeth Islands zeigen, dass dort ein Gebiet sehr hoher Akkumulation $\left(>40 \mathrm{~g} \mathrm{~cm}^{-2} \mathrm{a}^{-1}\right)$ auf den Hängen zur Baffin Bay und ein solches geringer Akkumulation $\left(<15 \mathrm{~g} \mathrm{~cm}^{-2} \mathrm{a}^{-1}\right)$ in den inneren Teilen des nördlichen Ellesmere Island vorhanden ist. Die Ablationsraten im Sommer zeigen auf denselben Eiskappen weit geringere regionale Schwankungen, mit Ausnahme niedrigerer Raten längs des nordwestlichen Randes der Inseln und möglicherweise auch auf den Hängen zur Baffin Bay. Doch, besteht eine engere Beziehung zwischen Ablation und Meereshöhe, die unterhalb der Firnlinie exponentiellen Charakter hat. Aus dem ${ }^{18} \mathrm{O}-\mathrm{Gehalt}$ des Schnees ergibt sich, dass aus der Baffin Bay beträchtliche Mengen von Feuchtigkeit $(>20 \%$ der Gesamtmenge) auf die Hänge zur Baffin Bay gelangen. Als weitere, wenn auch bei weitem schwächere Feuchtigkeitsquelle ist der Arktische Ozean anzusehen. Die $\delta^{18} \mathrm{O}-$ Daten zeigen zwei Auswirkungen auf die Kondensationsprozesse, eine orographische (d.h. durch adiabatsche Abkühlung) und eine in Abhängigkeit von der Entfernung zur Quelle (isobarische Abkühlung), wobei die Quelle irgendwo im Südosten der
Inseln liegt.

\section{INTRODUCTION}

During the spring of 1974 a series of oversnow traverses were made by a field party of four, including the author, over most of the large ice caps in the Queen Elizabeth Islands of Arctic Canada (Fig. I). These were made to provide basic background glaciological data needed for a continuing paleoclimatic ice-core program in the same area (Paterson and others, 1977; Koerner, 1977[a]). Glaciological work in the area prior to the present studies had largely been confined to isolated ice caps on Melville and Meighen Islands (Arnold, I965; Spector, I966; Paterson, I969), on the White Glacier and other nearby glaciers of Axel Heiberg Island (Müller, I963), on the ice shelves and ice caps of northern Ellesmere Island (Hattersley-Smith and others, 1960; Hattersley-Smith, 1963), and on the Devon Island ice 
cap (Koerner, 1970). Very little information was available for the south, central, and northeastern ice caps and also for the main ice cap on Axel Heiberg Island. Echo-sounding work by the Polar Continental Shelf Project on all these ice caps has already been published (Paterson and Koerner, I974; Koerner, $1977[\mathrm{c}]$ ), and it is the purpose of this paper to present and discuss the traverse data pertaining to snow accumulation and its ${ }^{18} \mathrm{O}$ content, and also to collate ablation data from the same area. The electrolytic conductivity and particle content and $10 \mathrm{~m}$ temperature distribution of the snow will be published elsewhere.

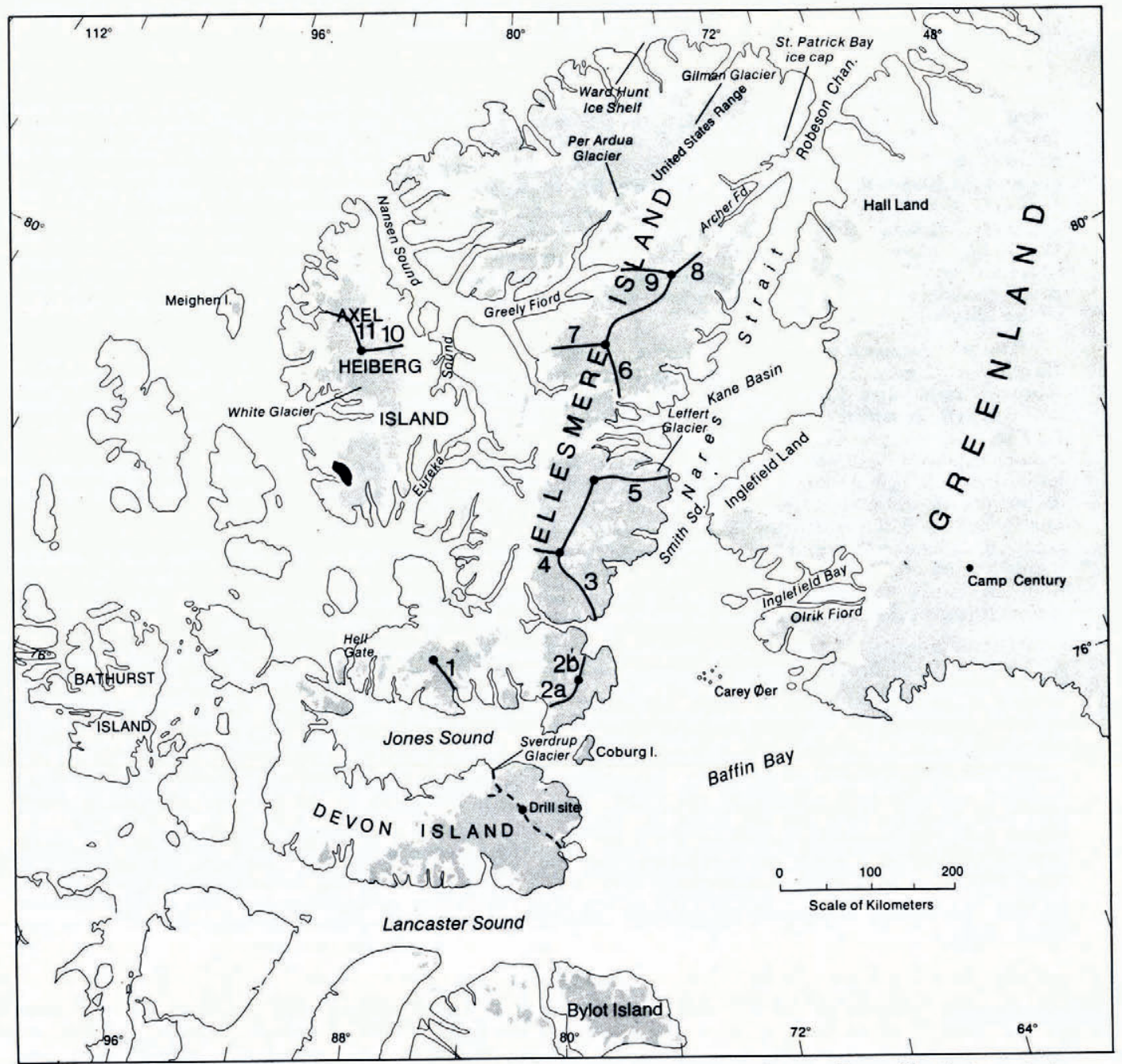

Fig. I. Location of I $2 \mathrm{~m}$ core sites (dots) and oversnow traverse routes. The broken line on Devon Island represents traverses done before 1974 .

\section{Methods}

Travel was by snowmobile hauling Nansen-type sleds. Elevations were taken with two Paulin altimeters and have been corrected for temperature but not for regional pressure differences occurring en route. However, closures from sea-level to sea-level indicate the final elevations are correct to $\pm 25 \mathrm{~m}$. 
Surface snow samples were collected in a plexiglass tube every $70 \mathrm{~m}$ change of elevation and immediately transferred to self-sealing plastic ("Whirlpak") bags. As each sample was taken by pushing the tube down vertically from the May or June 1974 surface until it reached the underlying melt surface of the previous summer, it represents the period August I973May/June 1974. On return to Resolute Bay these samples were weighed, melted, and poured into $20 \mathrm{ml}$ plastic bottles. They were then refrozen and sent in the frozen state to the Geophysical Isotope Laboratory in Copenhagen for. ${ }^{18} \mathrm{O}$ analysis.

Cores to I2 $\mathrm{m}$ were taken with a standard SIPRE corer at the sites indicated (Fig. I). The cores were measured and weighed on site. Accumulation rates were determined by calculating the water equivalent of cores down to a heavy melt layer formed during the unusually warm summer of 1962 (Koerner, 1970). This layer is readily recognizable as a very dense, coarse-grained melt layer underlying three annual layers of either completely unmelted or slightly melted snow representing the years $1962-63,1963-64$, and $1964-65$. The juxtaposition of three such unusually "dry" layers (dry in the sense of no summer melt) and one underlying "wet" layer represents an excellent datum level for accumulation studies. Each datum was confirmed by tritium analysis of samples taken from just below the r 962 summer

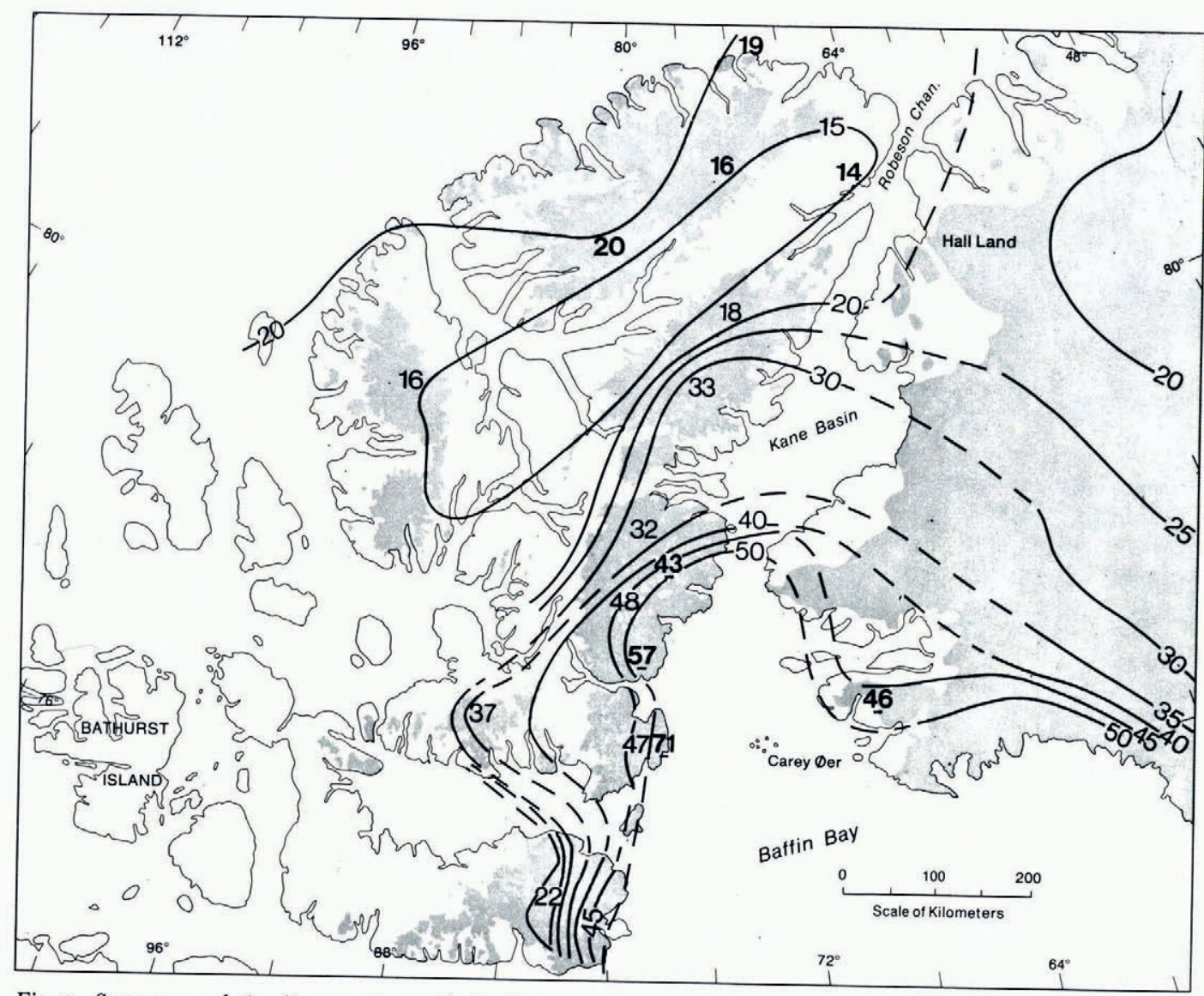

Fig. 2. Snow accumulation (in $\mathrm{g} \mathrm{cm}^{-2}$ year-1) for the period August 1962 to August 1973 in the eastern Queen Elizabeth Islands as calculated from measurements made down to the 1962 summer melt-layer in April and May 1974. Bold-faced values are from Hattersley-Smith and Serson (1973) and bold-faced values underlined are from Müller and others (I977). The isohyets on Greenland are from Mock $(1967)$; the broken lines are interpolations. 
level up through the 1963 and 1964 summer levels and containing the 1963 radioactive peak level (Koerner and Taniguchi, I976, and personal communication from H. Taniguchi).

\section{Results}

\section{Accumulation}

The core results, which represent the period $1962-73$, have been plotted and contoured in Figure 2; additional data have been incorporated from sources referenced in the figure caption. Accumulation-rate values from the weather stations have not been included as they universally give anomalously low values. Walker and Lake ( $\left[{ }^{C}{ }\right.$ 975] $)$ have discussed this same problem at length, and they also concluded that the weather-station values seriously underestimate the snow accumulation. A similar map has also been compiled from the surface snow-layer data. The mean value for each traverse has been plotted at the traverse's geographical mid-point (Fig. 3). In this case, the weather-station snow accumulation values fit into the general pattern well, and this may be due to improved methods of accumulation measurement at the stations introduced prior to 1973 .

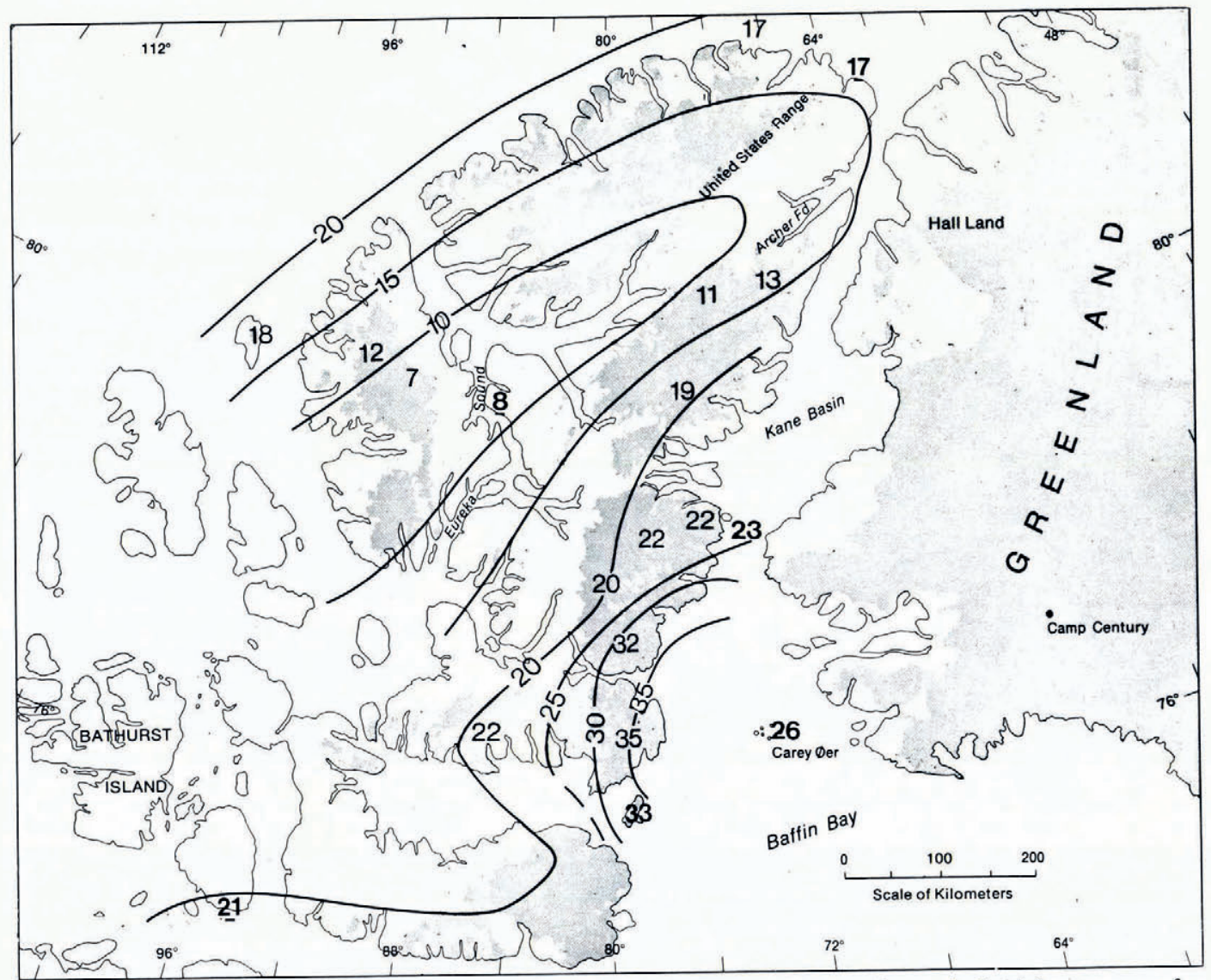

Fig. 3. Snow accumulation (in $\mathrm{g} \mathrm{cm}^{-2}$ year ${ }^{-1}$ ) for the period August 1973 to June 1974 as calculated from snow surface measurements in April and May 1974. Underlined bold-faced values are from the weather stations; bold-faced values are from $F$. Müller (personal communication). 
The regional accumulation-rate distribution of the Queen Elizabeth Islands is very similar between the two maps (Figs 2 and 3 ). The two dominant features are: a dry area centered over western Axel Heiberg and north-central Ellesmere Islands, and a moist area around northern Baffin Bay. I will now consider the Baffin Bay area. The high accumulation rate on these slopes was first discovered during studies of the Devon Island ice cap by Koerner ( 1966 ) and is now the subject of intense studies by F. Müller and coworkers (personal communication). Mock ( 1968 ) also found very high accumulation rates in Greenland on southerly slopes facing Baffin Bay. The area, which we might consider bounded by the $40 \mathrm{~cm}$ isohyet (Fig. 2), extends on the Canadian side of Baffin Bay from the top of the ice fields and ice caps facing Baffin Bay down to sea-level (Figs 2 and 3). The 1973-74 accumulation rate for Carey Øer in Baffin Bay (personal communication from F. Müller) is lower than that of the surrounding ice-cap slopes which, if representative both spatially and temporally, means that Baffin Bay itself is not part of the high-accumulation area. In addition, accumulation measurements on Bylot Island, made in 1975 by the author, showed that in that year the island was outside the high-accumulation area. The general appearance of the glaciers with a generally high ice-edge along the northern coast of Bylot Island, suggests this is typically the case. The high-accumulation area does not, therefore, extend south of Devon Island. The area of highest accumulation on the Greenland side of Baffin Bay appears to be on the south-facing slopes below Camp Century where accumulation rates reach $80 \mathrm{~g} \mathrm{~cm}^{-2}$ year-1 (Mock, I 968); the detailed pattern between Inglefield Bay and Inglefield Land is not known, but in general the isohyets show no unusual trends between the Queen Elizabeth Islands and Greenland (Fig. 2). The boundary of the high-accumulation area on Ellesmere and Devon Islands is quite sharp in places although the smoothing introduced by the contours in Figures 2 and 3 masks this effect. The steepest part of the gradient is on the uppermost parts of the shadowed west-facing slopes of central Ellesmere Island. For example, measurements of the current balance-year layer in May I 966 showed there was a decrease by $50 \%$ in the accumulation-rate on the west side of the central Ellesmere Ice Cap within $2 \mathrm{~km}$ of the crest. This emphasizes that the main mechanism in producing the high accumulation-rate is an orographic one, but this will be discussed more fully later. On the southern side of the Thule peninsula in Greenland (Figs I and 2) the accumulation gradient was $0.4 \mathrm{~g} \mathrm{~km}^{-1}$ for the 3 year period $1962-65$ (Mock, I968). This is especially steep.

There are substantial variations in the accumulation-rate within the high accumulation region, the most important of which, ignoring the complex topographically induced variations, is a general decrease in accumulation with increasing distance from Baffin Bay. This is not always a linear decrease, however, as repeated profiles from the south-east side of Devon Island ice cap in June 1962,1963 , and 1965 (Koerner, I966) and 1967 and 1972 (Fig. 4) have shown. In that area maximum accumulation occurs over a broad zone below $900 \mathrm{~m}$ a.s.l.; above that elevation there is an inverse relationship between elevation and accumulation-rate each year which may be a distance-from-source effect. This pattern indicates that most of the precipitation is from low cloud bases although, on Devon Island at least, the ice cap's own circulation may be sufficiently strong above $900 \mathrm{~m}$ a.s.l. to restrict the effects of Baffin Baysteered cyclones. It is tempting to attribute the high accumulation on the ice caps facing Baffin Bay to the effect of the polynya there; this is usually termed the North Water. The question is whether the presence of a low-pressure cell in northern Baffin Bay draws in moist air masses from further south to deposit moisture on the surrounding ice caps, or whether the moisture is from the polynya itself. The answer to this question has fairly important paleoclimatic implications as it seems highly likely that the polynya did not exist during the Wisconsin period (Koerner, 1977[b]).

Moisture advection into the Baffin Bay area is greatly enhanced by the thermal effect of open water and/or thin ice on air masses. This effect draws and steers cyclones to increase convection and hence precipitation. However, Schriber and others (1977) using local $\delta^{18} \mathrm{O}$ 


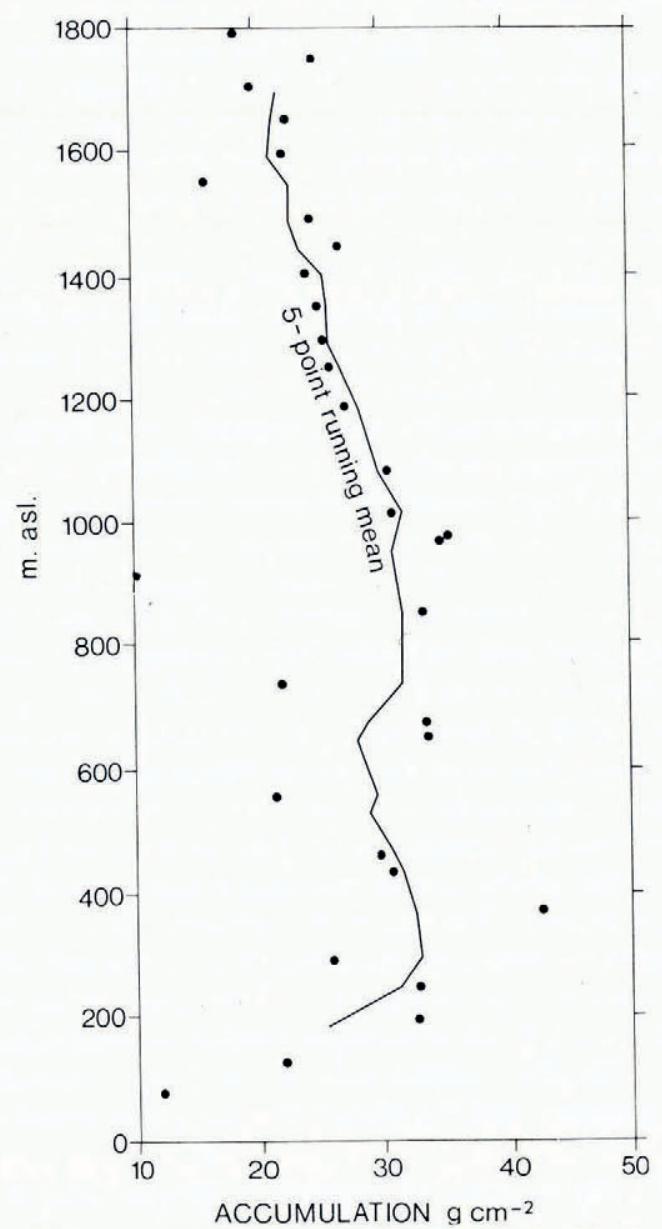

Fig. 4. Snow accumulation (in $\mathrm{g} \mathrm{cm}^{-2}$ year ${ }^{-1}$ ) for the south-east side of Devon Island for the period August $197 \mathrm{I}_{\text {Io }}$ June 1972.

data calculated that $17 \%$ of the moisture deposited on Coburg Island was from Baffin Bay itself for the period November 1972 to May i973. The computations were based on a calculated value for moisture entirely of Baffin Bay origin ( $\delta \mathrm{BB})$ (Schriber and others, 1977) and the relationship

$$
w=\frac{100(\delta \mathrm{c}-\delta \mathrm{s})}{(\delta \mathrm{c}-\delta \mathrm{BB})},
$$

where $w$ is the percentage of moisture from Baffin Bay, $\delta \mathrm{c}$ is the $\delta$ value of precipitation with no local contribution (taken from an empirical relationship between measured values of temperature and $\delta$ at Coburg Island), and $\delta$ s is the measured $\delta$ value of precipitation on Coburg Island. Koerner and Russell (in press), using the same approach, calculated a $26 \%$ contribution from Baffin Bay to sea-level coastal accumulation using their own $\delta^{18} \mathrm{O}$ data from the south-east side of Devon Island representing the period August 1971 to late June 1972. They also calculated that at the top of this ice cap the local contribution to moisture was only $8 \%$. Suffice it to say that the fractional oxygen isotope content of the accumulation indicates that a substantial contribution is made to ice-cap accumulation in this area by Baffin Bay. 
The accumulation-rate difference between the high-accumulation area and that immediately beyond it (and I would stress here that while there is a general accumulationrate decrease from Baffin Bay westwards and north-westwards there is a very steep isohyetal gradient along much of the upper and therefore western edge of the high accumulation area) is from an average of 45 to one of $<32 \mathrm{~g} \mathrm{~cm}^{-2}$ year $^{-1}$; i.e. a drop of about $30 \%$. Thus, while the possibility of local, i.e. Baffin Bay moisture being deposited further afield cannot be discounted, it is possible that the excess accumulation on the slopes facing Baffin Bay is largely from the bay itself.

There is also a slightly higher accumulation-rate along the north-west coast of Ellesmere and Meighen Islands compared to the interior regions further to the south-east. This may be due to the adjoining Arctic Ocean acting as a moisture source or an orographic effect causing precipitation of moisture originating from a much more distant source. The accumulation increase does not of itself prove the Arctic Ocean is a moisture source, but I will return to this when discussing the oxygen-isotope results.

Whatever the cause, however, the accumulation increase is much more restricted than that around Baffin Bay, so that the general accumulation-rate decrease into the dry Ellesmere interior is only in the order of $5 \mathrm{~g} \mathrm{~cm}^{-2}$ year-1 compared to $30 \mathrm{~g} \mathrm{~cm}^{-2}$ year-1 from Baffin Bay. Koerner (1973) in fact showed there was a significantly higher accumulation-rate around the periphery of the Arctic Ocean ice pack for some $400 \mathrm{~km}$ offshore. These increases were of the order of 2.5 to $5.0 \mathrm{~g} \mathrm{~cm}^{-2}$ year-1 $^{-1}$ and were attributed to greater cyclonic activity there compared to the central Arctic Ocean. The much more rapid increase along the north-west Ellesmere coast must depend on orographic uplift.

The dry area, according to the present data, centers around the western Ellesmere fiords and the Nansen and Eureka Sounds (Figs I, 2, and 3). The low accumulation-rates here are due to the shadowing effect of the surrounding mountains with Axel Heiberg Island reaching I $850 \mathrm{~m}$ to the west, northern Ellesmere Island $2000 \mathrm{~m}$ to the north, and central Ellesmere Island I $800 \mathrm{~m}$ to the east. The area is also separated from southern moisture sources by high-lying areas on south-west Ellesmere and Devon Islands, so that air masses generally descend into the area and heat adiabatically to form dry rather than moist air.

Over many areas of the Earth's surface there is a positive relationship between precipitation and elevation. Such a situation does not appear in the present data from the Queen Elizabeth Islands (Table I). In the few cases where there is a weak but significant relationship between accumulation and elevation it is probably due to wind-drift and removal of snow

TABle I. CoRrelation COEFFICIENTS $r$ AND SIGNIFICANCE LEVELS FOR ${ }^{18} \mathrm{O}$ AND ACCUMUlation VERSUS ELEVATION ON VARIOUS TRAVERSES IN THE EASTERN QUEEN ELIZABETH ISLANDS FOR THE PERIOD AUgust 1973 TO MAY/JUNe 1974

\begin{tabular}{|c|c|c|c|c|c|}
\hline \multirow[b]{2}{*}{ Traverse } & \multicolumn{2}{|c|}{$\begin{array}{l}\text { Correlation coefficients } \\
\text { against elevation }\end{array}$} & \multirow{2}{*}{$\begin{array}{l}\text { Elevation } \\
\text { interval } \\
\text { sampled } \\
\mathrm{m} \text { a.s.l. }\end{array}$} & \multicolumn{2}{|c|}{$\begin{array}{c}\text { Significance } \\
\text { level of correlation }\end{array}$} \\
\hline & ${ }^{18} \mathrm{O}$ & Accumulation & & ${ }^{18} \mathrm{O}$ & Accumulation \\
\hline I & 0.5 & 0.3 & I $433^{-}$ & $5 \%$ & n.s. \\
\hline $2 \mathrm{a}$ & $0.3^{2}$ & 0.76 & 903- & n.s.* & $<\mathrm{r} \%$ \\
\hline $2 b$ & 0.17 & o. I I & $903^{-}$ & n.s. & n.s. \\
\hline 3 & 0.82 & 0.04 & I $263-$ & $<0.1 \%$ & n.s. \\
\hline 4 & 0.36 & 0.83 & I $263-200$ & n.s. & $<5 \%$ \\
\hline 5 & $0.5^{2}$ & 0.32 & I $696-\quad 0$ & $<5 \%$ & n.s. \\
\hline 6 & 0.17 & $0.6 \% 8$ & I 754- & n.s. & $<0.1 \%$ \\
\hline 8 & 0.17 & 0.02 & 1 $827-1052$ & n.s. & n.s. \\
\hline 9 & 0.05 & 0.46 & I $827-\quad 0$ & n.s. & n.s. \\
\hline 10 & 0.25 & 0.54 & I $810-807$ & n.s. & $<5 \%$ \\
\hline II & 0.44 & 0.50 & I $810-$ & $5 \%$ & $5 \%$ \\
\hline
\end{tabular}


from the lower elevations. However, the surface-snow samples represent only a ro month period which may introduce excessive noise into any such statistical analysis. This is not the case with the core results which represent an I I year period (August 1962 to August 1973). A multiple regression analysis between these data and latitude in degrees and tenths $(z)$ and elevation in meters a.s.l. (h) gives the relationship

$$
c=265.25-2.95 \text { I } z-0.00326 h,
$$

where $c$ is the accumulation in $\mathrm{g} \mathrm{cm}^{-2}$ year $^{-1}$. Equation (2) (where the coefficient of correlation $r=-0.62$ significant at the $\mathrm{I} \%$ level) confirms that there is indeed very little relationship between elevation and accumulation which, overall, is an inverse one. On the other hand, there is a much stronger relationship with latitude which, however, is another expression of what will later be shown to be a prime relationship between accumulation-rate and distance from moisture source and/or distance from the first orographic uplift of moisture-laden air masses.

\section{Ablation}

At present the Polar Continental Shelf Project continues to measure the mass balance of the ice caps on Melville, Meighen (Arnold, r965; Paterson, r969), and Devon Islands (Koerner, 1970). From these data, and the work of others, accumulation and ablation values for the Queen Elizabeth Islands have been collated (Table II). Because of the diversity of glacier types, aspect, albedos, and periods it is difficult to detect any regional trends within these data. The only significant regionalism in the data is the very low ablation rates on the Ward Hunt ice rise and the Meighen Ice Cap (Table II). They are in fact the only sizeable ice masses in the Canadian Arctic existing entirely below $300 \mathrm{~m}$ a.s.l. Hattersley-Smith and Serson (1970) attributed the low ablation on the Ward Hunt ice rise to high prevalence of

Table II. Accumulation and ablation rates for various periods in the Canadian Arctic

\begin{tabular}{|c|c|c|c|c|c|}
\hline Glacier & $\begin{array}{l}\text { Approximate } \\
\text { elevation } \\
\text { m a.s.l. }\end{array}$ & $\begin{array}{l}\text { Period } \\
\text { of study }\end{array}$ & $\begin{array}{c}\text { Accumulation } \\
\text { rate } \\
\mathrm{kg} \mathrm{m}^{-2} \text { year }^{-1}\end{array}$ & $\begin{array}{c}\text { Ablation } \\
\text { rate } \\
\mathrm{kg} \mathrm{m}^{-2} \text { year }^{-1}\end{array}$ & Reference \\
\hline Barnes Ice Cap & $45^{\circ}$ & $1974-76$ & & 2070 & Ommanney (1977) \\
\hline Devon ice cap & $\begin{array}{l}\text { sea-level } \\
0-1300\end{array}$ & $\begin{array}{l}196 \mathrm{I}-76 \\
196 \mathrm{I}-76\end{array}$ & & I 380 & R. M. Koerner, on file \\
\hline Melville Island & & $1963-75$ & 230 & $35^{\circ}$ & $\begin{array}{l}\text { Personal communication } \\
\text { from W. S. B. Paterson }\end{array}$ \\
\hline Leffert & $0-500$ & & & $900+$ & $\begin{array}{l}\text { Personal communication } \\
\text { from G. Holdsworth }\end{array}$ \\
\hline White Glacier & $\begin{array}{l}\text { sea-level } \\
1_{50}-85^{0}\end{array}$ & $\begin{array}{l}1960-62 \\
1960-62\end{array}$ & 150 & $\begin{array}{l}294^{\circ} \\
1000\end{array}$ & $\begin{array}{l}\text { Müller (1963) } \\
\text { Arnold (1965) }\end{array}$ \\
\hline Meighen Ice Cap & $50-250$ & 1959-76 & 200 & 300 & $\begin{array}{l}\text { Personal communication } \\
\text { from W. S. B. Paterson }\end{array}$ \\
\hline St Patrick Bay & c. $75^{0}-850$ & $1974-76$ & 160 & 180 & $\begin{array}{l}\text { Hattersley-Smith and Serson } \\
(\text { (1970) }\end{array}$ \\
\hline Gilman Glacier & $400-1100$ & I 956-59 & 70 & $510+$ & $\begin{array}{l}\text { Hattersley-Smith and others } \\
(1960)\end{array}$ \\
\hline Ward Hunt Ice Rise & sea-level & $1959-76^{*}$ & I 30 & 250 & $\begin{array}{l}\text { Hattersley-Smith and Serson } \\
\text { (1970); Ommanney } \\
\text { (1977) }\end{array}$ \\
\hline Per Ardua Glacier & $45^{0}-1150$ & 1967-68 & & I 160 & Ommanney (1977) \\
\hline Decade Glacier & $45^{0-1} 050$ & $1965-70$ & 210 & 680 & Ommanney (1977) \\
\hline Coburg Island & c. $5^{0-} 500$ & I974-75 & & I 100 & $\begin{array}{l}\text { Personal communication } \\
\text { from F. Müller }\end{array}$ \\
\hline
\end{tabular}


fog there; this is an Arctic Ocean effect. Alt ([1975]), in a more sophisticated analysis of weather and mass balance, considered the Meighen Ice Cap to owe its existence at such a low elevation to its proximity to the Arctic Ocean which, while it may not act as an important heat sink in summer, does not act as a heat source either. The surrounding land masses, on the other hand, once snow-free, do act as a heat source to air masses moving over them thereby limiting the low-ablation region to a narrow zone along the Arctic Ocean periphery.

Holmgren (197 I) considered that Baffin Bay cyclones by advecting cold air-masses into the high-accumulation region promote lower ablation rates on the lower ice-cap slopes and bring accumulation in summer to the upper parts of the ice cap. Supporting this conclusion is the absence of any increase in ice layering in the firn moving eastwards along the summit ridge of the Devon Island ice cap despite increasing $12 \mathrm{~m}$ firn temperatures in that direction (Koerner, I966). This combined ice-layer/temperature evidence suggests an overall Baffin Bay warming effect for the whole year but a specific cooling effect for the summer season. On the other hand, Koerner's (1970) ablation/elevation profiles from the Devon Island ice cap show no sign of a Baffin Bay effect. However, these profiles do not run directly down to Baffin Bay but south to Lancaster Sound and the south-facing aspect of these glaciers, which increases radiation input, may compensate for any Baffin Bay effect. They are probably not representative of the true Baffin Bay slopes.

To examine the regional variation of melting further, values for the amount of ice-layering in each core for the I I year period $1962-73$ have been studied. Ice-layer thicknesses were summed for the cores between the 1962 summer surface and the 1973 summer surface. The thicknesses $\left(L_{\mathrm{h}}\right)$ were corrected $\left(L_{\mathrm{c}}\right)$ to allow for initial density variations from site to site according to

$$
L_{\mathrm{c}}=L_{\mathrm{h} \rho_{0}}-L_{\mathrm{h} \rho}
$$

where $\rho$ is the mean density of the surface snow at that site, $\rho_{0}=0.9 \mathrm{Mg} \mathrm{m}^{-3}$, and $L_{\mathrm{h}}$ is the thickness of the ice layer. This correction to the ice-layer thickness gives the amount of water refrozen to form each ice layer. I should stress here that the ice-layer amount is not a measure of the total melt as this includes melt water formed and refrozen in a more uniform way throughout the firn pack and not in layer form. However, a previous study by Koerner (1977[b]) has shown that there is a strong relationship between the amount of ice layering formed each summer at the top of the Devon Island ice cap and the annual mass balance for the north-west side so that it is pertinent to include the core ice-layer data in the present discussion of regional variation of ablation.

The ice-layer values are shown in Table III. In this case all the sites are well above the firn line, and are similar in aspect and albedo; the data also refer to the same time-period. The differences between the sites are therefore reduced to those of elevation and geographical position. A multiple-regression analysis between total melt for the I I year period in grams

TABle III. Total Melt-WATER REFrozen IN ICE LAYER Form AT EACH CORE SITE for the period August ig62 to May/June 1973 Eastern Queen Elizabeth Islands

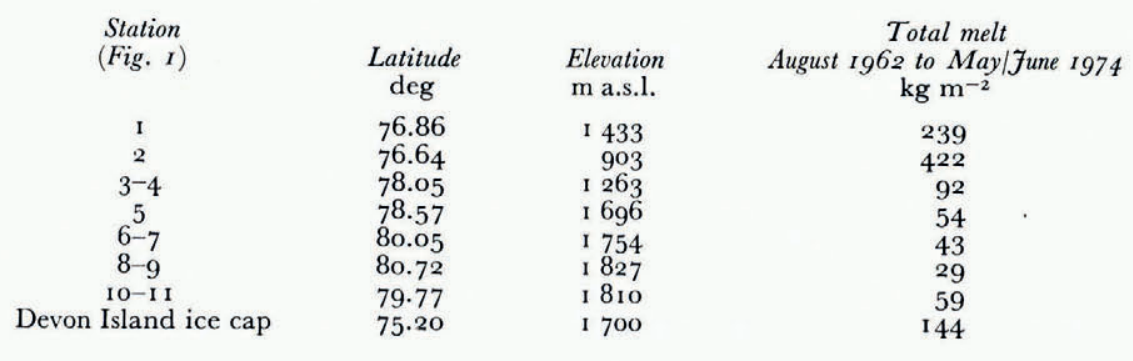


water equivalent $(m)$, latitude in degrees and tenths $\left(x_{1}\right)$, and elevation in meters a.s.l. $\left(x_{2}\right)$ gives

$$
m=219.5-2.06 x_{1}-0.0292 x_{2} .
$$

This equation (where the coefficient of correlation $r=0.89$, significant at the $<\mathrm{r} \%$ level) shows that elevation is the dominant variable, with latitude accounting for only $13 \%$ of the computed variation and elevation for the rest. From it one can calculate the dry-snow-line elevation, i.e. where $m=0$. We calculate $2240 \mathrm{~m}$ a.s.l. for lat. $75^{\circ} \mathrm{N}$., I $885 \mathrm{~m}$ a.s.l. for lat. $80^{\circ} \mathrm{N}$., and I $55^{\circ} \mathrm{m}$ a.s.l. for lat. $85^{\circ} \mathrm{N}$. These values are reasonable as Benson ( 1962 , p. 93) found the dry-snow line in Greenland at elevations of $2360 \mathrm{~m}$ and $\mathrm{i} 720 \mathrm{~m}$ at lat. $75^{\circ} \mathrm{N}$. and lat. $80^{\circ} \mathrm{N}$. respectively.

However, the analysis gives much too low a melt value for sea-level, i.e. less than 2 I9o $\mathrm{kg} \mathrm{m} \mathrm{m}^{-2}$ at lat. $75^{\circ} \mathrm{N}$. compared to a measured ablation rate at sea-level on Devon Island of over io $380 \mathrm{~kg} \mathrm{~m}^{-2}$ for the same i i year period. To bring the two sets of sea-level values

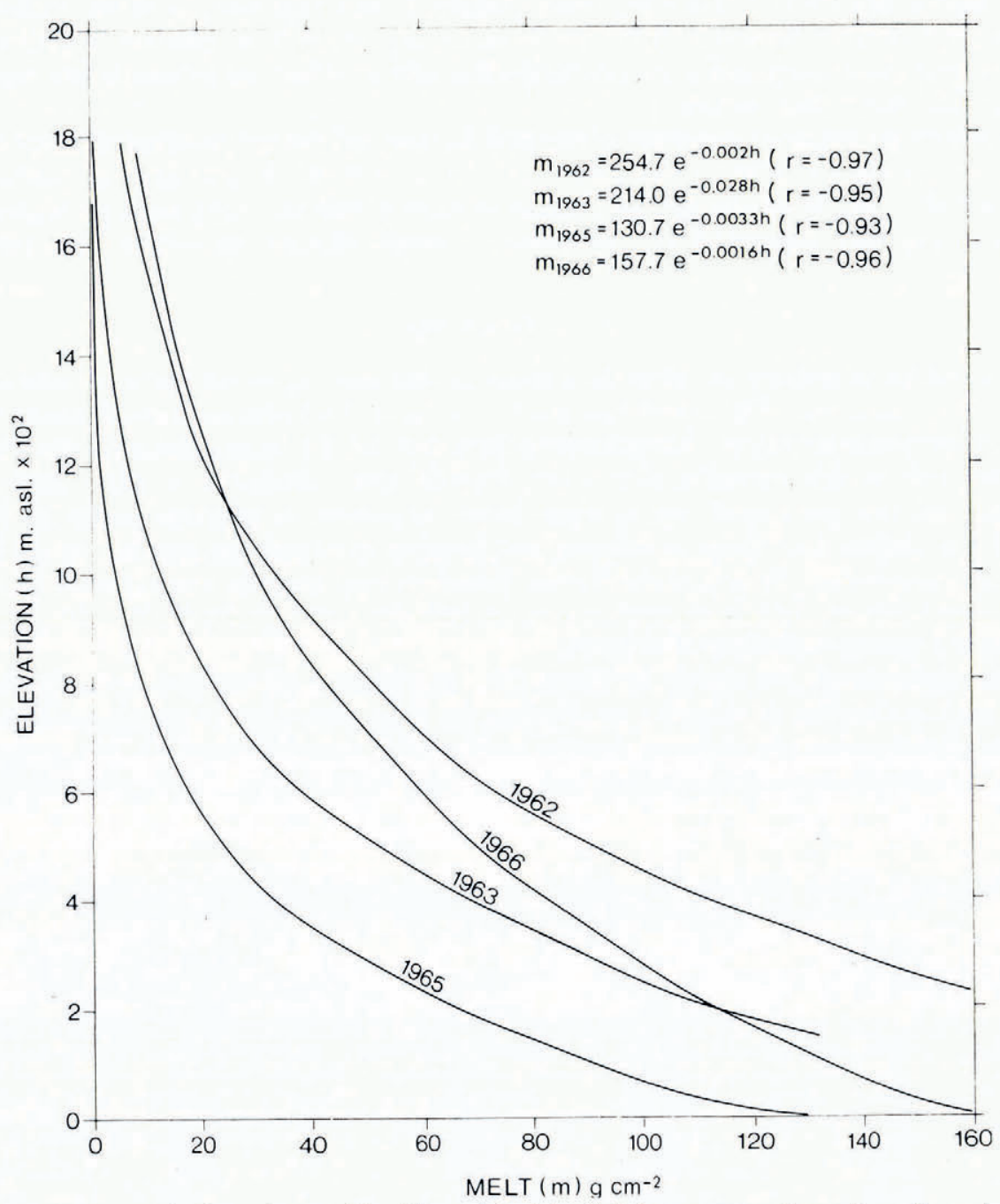

Fig. 5. Melt total for the north-west side of Devon Island for the balance years, $1962,1963,1965$, and 1966 . 
into agreement would mean assuming that the ice layers represent only about $20 \%$ of the total melt occurring each summer at each core site; this is unrealistic.

As the core sites are all well above the firn line in each area, values for total melt from the Devon Island studies for the four summers I962, I963, I965, and I 966 have been used to extend the melt/elevation relationship down to sea-level. These values were calculated below the equilibrium-line elevation by adding snow melt to ice melt, between the equilibriumline elevation and firn line by adding snow melt to subsequent superimposed-ice melt, and above the firn line by calculating a total melt under the assumption that the snow-density change in the active melt layer (identified by its grain shape) is entirely due to melt and not to compaction following grain-shape changes. Ignoring compaction is believed to introduce only a small error.

The values regressed against elevation show a good fit to an exponential equation of the form $m=a \exp (-b h)$ where $m$ is melt rate in mass per unit area per unit time and $h$ is elevation in meters above sea-level. The $r$ coefficients and curves are all shown in Figure 5 . Such a relationship explains why the linear fit between the melt values and elevation gives such a low sea-level value; its implications will be discussed later.

\section{Oxygen isotopes}

Dansgaard and others (1973) have shown a strong relationship between the fractional ${ }^{18} \mathrm{O}$ content of snow $(\delta)$ and elevation $(h)$ on Greenland. Lorius (in press) found a much more complex $\delta$ distribution in parts of Antarctica largely due to less uniform atmospheric circulation there and to re-sorting of snow by wind-drift. Our $\delta$ picture (see Table I) is more similar to the Antarctic than the Greenland one.

The present data are derived from samples each of which covers only a io month accumulation period. D. Fisher (personal communication) found that the standard error of the $\delta$ value of any one year's snow from the Devon ice cores is of the order of $1 \%$. As studies by Dansgaard and others (1973) in Greenland and also R. M. Koerner and R. D. Russell* on the south-east side of Devon found a $\delta$ gradient with elevation of about $0.6 \%$ per $\mathrm{r}$ oo $\mathrm{m}$, we should be able to see a similar relationship in our data if it exists despite the $1 \%$ standard error of each sample. However, of the various profiles only three show a significant relationship between $\delta$ and elevation (Fig. 6 and Table I). The most highly significant relationship is for profile number 3 which extends inland from Baffin Bay. Its gradient of $0.64 \%$ per $100 \mathrm{~m}$ is similar to the $0.65 \%$ per $100 \mathrm{~m}$ for the Baffin Bay side of the Devon Island ice cap sampled in 1972 (R. M. Koerner and R. D. Russell*) and the $0.66 \%$ of Dansgaard and others (1973) in Greenland. Profile number 4 , which has a barely significant relationship between $\delta$ and elevation, lies $150 \mathrm{~km}$ to the north of number 3 and on the edge of the high Baffin Bay accumulation area. Profile I similarly has a barely significant relationship between $\delta$ and elevation. All three profiles must owe their relationship to the concurrence of precipitation events with winds moving directly up-slope, i.e. adiabatic cooling. We may consider that the more prevalent the occurrence of orographic precipitation the stronger the relationship. As the strongest relationships occur along the east side of the Devon Island ice cap where R. M. Koerner and R. D. Russell* found an $r$ value for $\delta / h$ of 0.97 (significant at the $<0.1 \%$ level) and the Baffin Bay side of the south-east Ellesmere Ice Cap, these two areas must get most of their snow accumulation from orographically induced precipitation.

The question immediately arises as to why profiles $2 \mathrm{a}$ and b (Figs I and 6) do not show a significant relationship when they also lie in the same high-accumulation area. It seems to be simply a matter of direction; the air masses move westward from Baffin Bay and up-slope and

\footnotetext{
* Paper in preparation entitled " $\delta^{18} \mathrm{O}$ variations in snow on the Devon Island ice cap, Northwest Territories, Canada".
} 


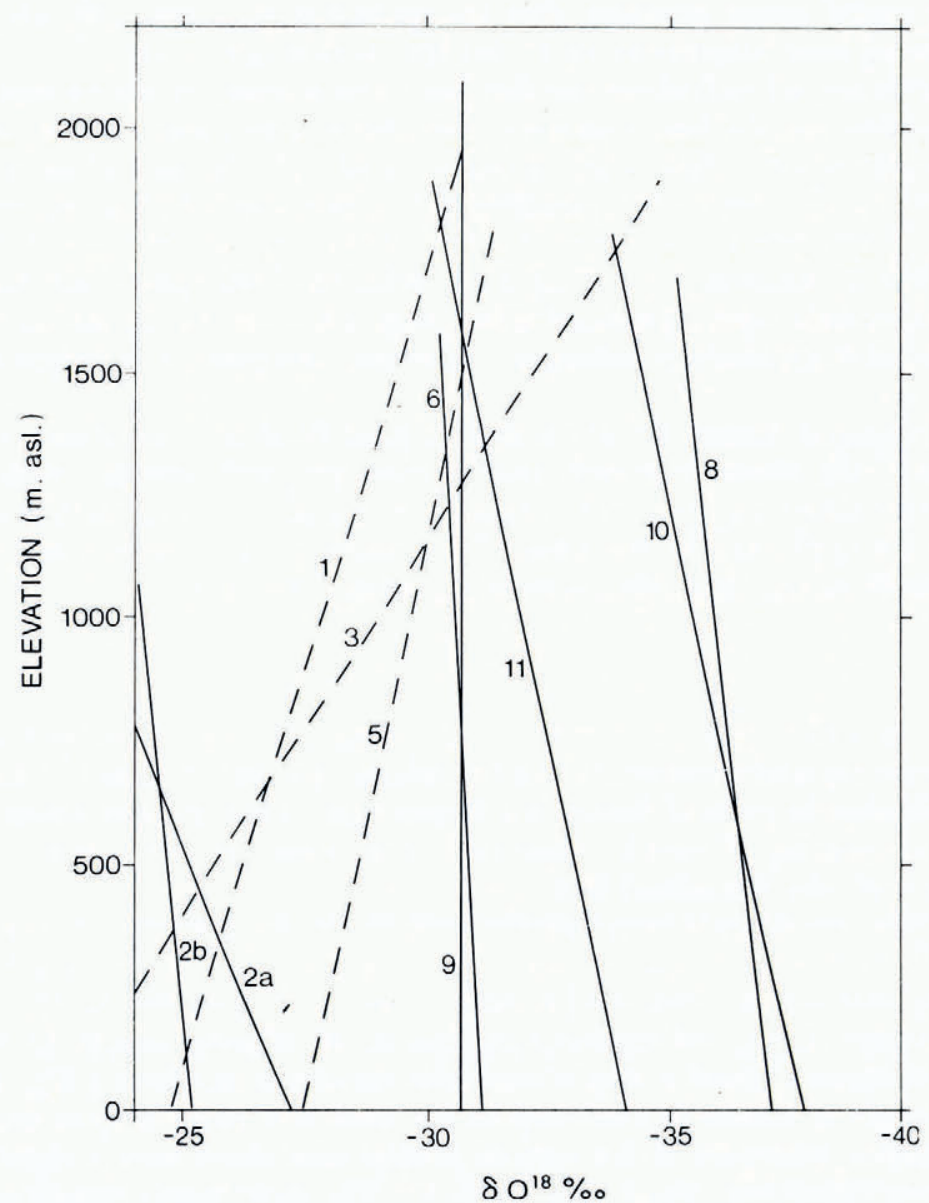

Fig. 6. ${ }^{18} \mathrm{O}$ profiles for the various traverses in the Queen Elizabeth Islands for the period August 1973 to May/June 1974 . For the location of each traverse by number refer to Figure $I$.

they cross profiles $2 \mathrm{a}$ and $\mathrm{b}$ without further uplift so that precipitation comes from a single condensation level.

The remaining profiles are similar to $2 \mathrm{a}$. However, while they too show no significant relationship between $\delta$ and $h$, the $\delta$ distributions do not at first sight seem to show a random, but rather a uniform, distribution with changing elevation. For example, most of the $\delta / h$ gradients are very similar with slightly positive values. So, to see whether the distributions between each profile are significantly different, a variance test was made. This test showed that the profiles divided into three separate groups. Within each group there is no significant difference in mean $\delta$ between each profile, but between each group the difference is significant at the $<_{\mathrm{r}} \%$ level. The distributions, then, are not random. First, the lack of a $\delta$ gradient with elevation may be explained in terms of precipitation coming from a single condensation level. This phenomenon has been described before in mountainous regions (Ambach and others, 1972). Secondly, the grouping is a consequence of increasing distance from the moisture source as the air mass is cooled isobarically and the heavier isotope depleted preferentially. Thus profiles $2 \mathrm{a}$ and $\mathrm{b}$ show the least negative values as they lie closest to the moisture source of the air mass as it penetrates the Queen Elizabeth Islands from the south-east. 
The profile most distant from the source, number I I (Figs I and 6), does not, however, show the most negative $\delta$ value, but rather profile number ro on the "dry side" of Axel Heiberg Island; this warrants discussion. We have already seen that snow accumulation increases slightly with approach to the Arctic Ocean from the south-east. The fact that the west side of Axel Heiberg Island is significantly warmer isotopically indicates the Arctic Ocean as a moisture source, albeit a small one. This is because any air mass that has moved from more southerly latitudes and cooled isobarically en route should show the most negative values along the Arctic Ocean littoral. The Axel Heiberg Island profiles strongly suggest this is not the case; so that some of the west Axel Heiberg Island moisture must be of Arctic Ocean origin. However, the west Axel Heiberg profile has a mean $\delta$ value only $3 \%$ more positive than the east Axel Heiberg profile, suggesting the Arctic Ocean contribution is quite small and restricted to a fairly narrow zone along its periphery. Alt's ([1975]) work on the meteorological conditions affecting nearby Meighen Island brought her to a similar conclusion.

We may further depict the regional $\delta$ variations in two ways. First, the average $\delta$ values have been plotted at the mid-point of each traverse and isolines drawn (Fig. 7). Secondly, the same mean $\delta$ values have been plotted as a function of distance from source in Figure 8 . The source-edge from which the distance has been measured is considered as a smooth coastline along eastern Devon and south and central Ellesmere Islands. This coast is close to the

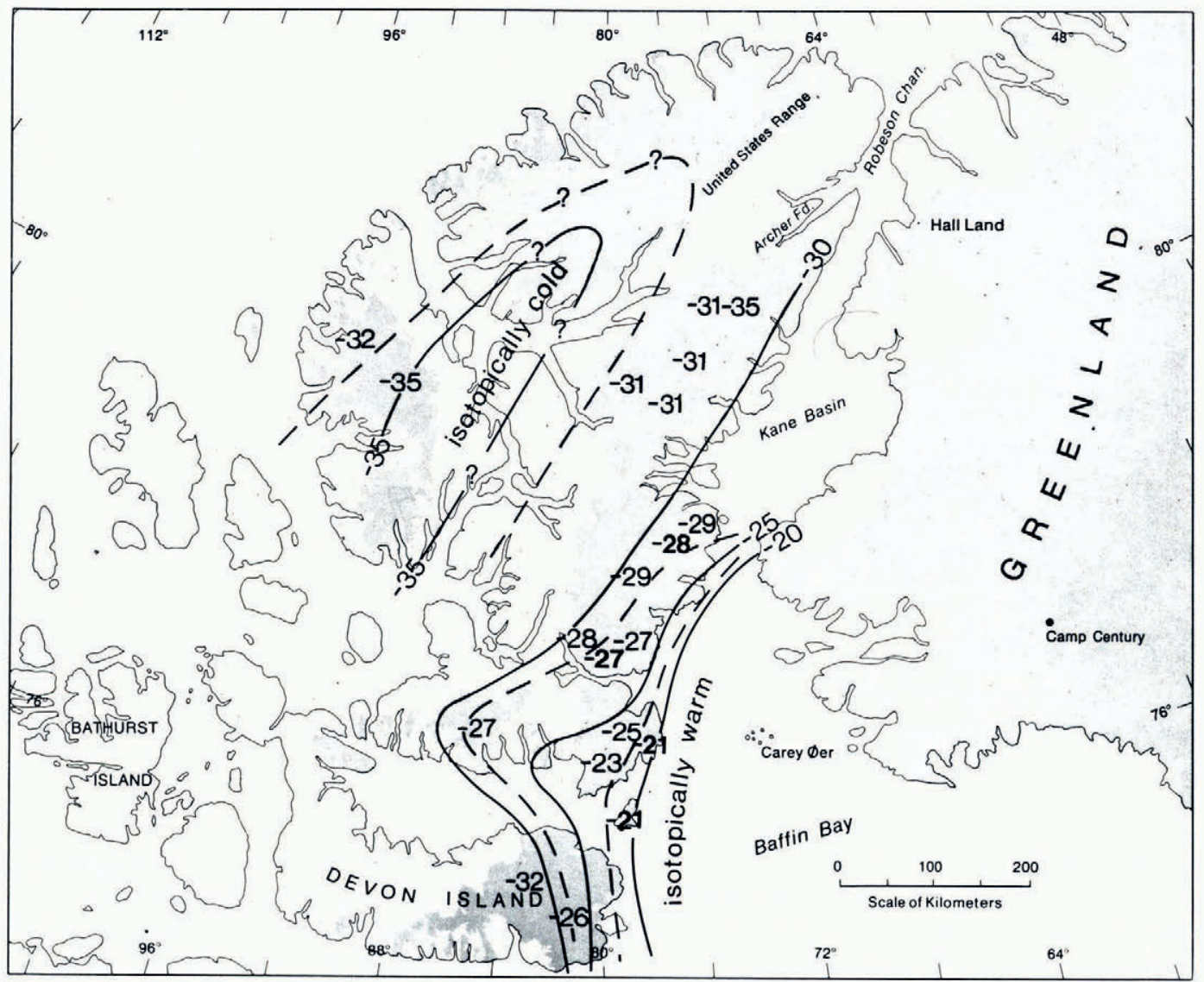

Fig. 7. ${ }^{18} \mathrm{O}$ values for the eastern Queen Elizabeth Islands for the period August 1973 to May/June 1974. Bold-faced values are from Müller and others (I977). The contour interval is $-2.5 \delta$ units. 
open-water edge during the winter months so that it represents the edge of the last moisture source available to the air mass before it crosses the Queen Elizabeth Islands. Both the map (Fig. 7) and graph (Fig. 8) show the relationship between $\delta$ and distance from source $(x)$ which a regression analysis shows to be

$$
\delta=-26.00-0.0195^{x},
$$

where $\delta$ is measured in parts per thousand and $x$ in kilometers. The correlation coefficient $(r)$ for this relationship is 0.78 (significant at the $<\mathrm{r} \%$ level). This means $6 \mathrm{r} \%$ of the $\delta$ distribution over the Queen Elizabeth Islands can be explained in terms of distance from a south-east source.

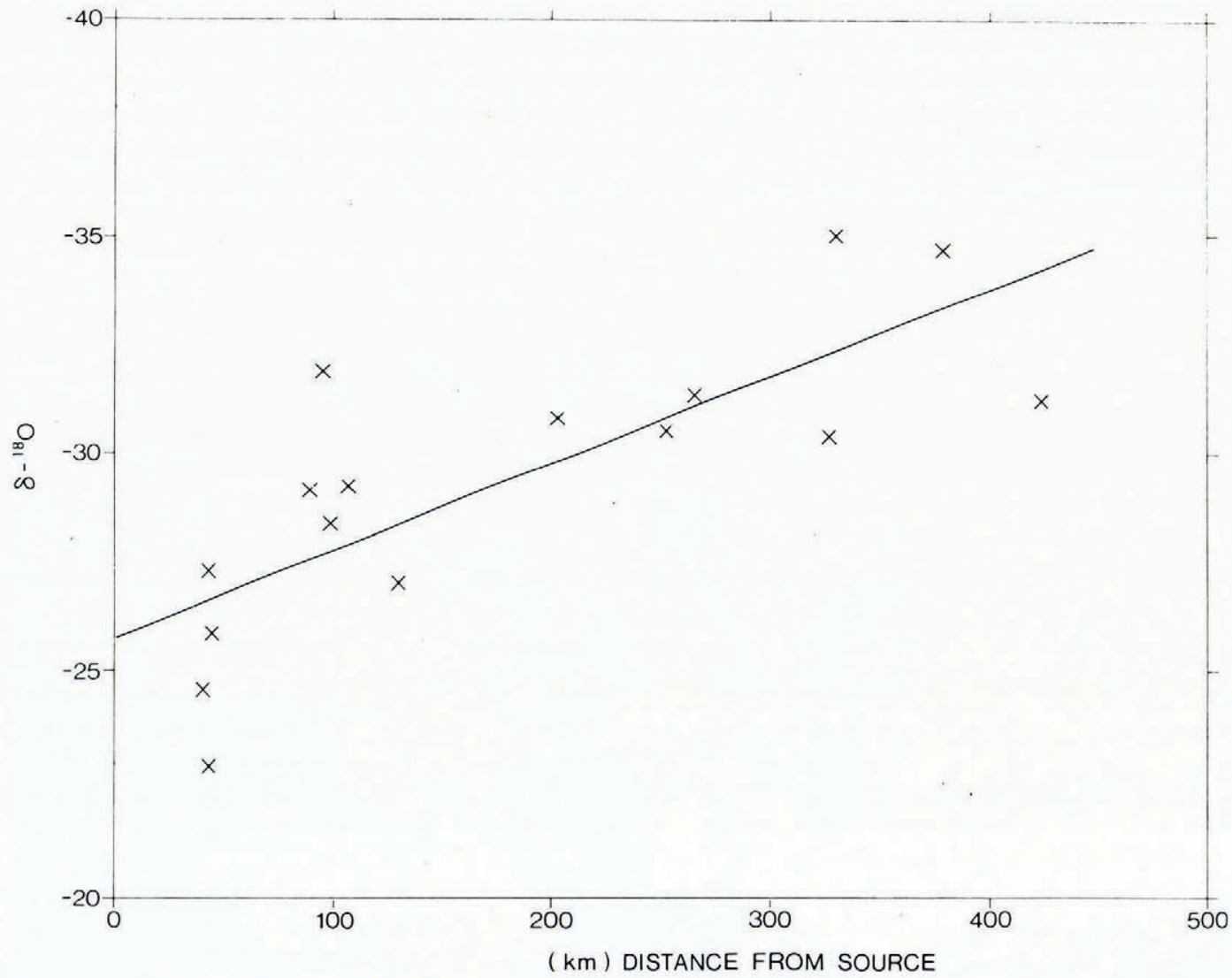

Fig. 8. Relationship between ${ }^{18} \mathrm{O}$ and the distance from moisture source, eastern Queen Elizabeth Islands for the period August 1973 to May/June 1974.

The overall picture, therefore, from the ${ }^{18} \mathrm{O}$ data is one of predominantly orographic precipitation along the slopes facing Baffin Bay but a general isobaric cooling as the air masses move north-westward over the rest of the eastern Queen Elizabeth Islands to bring precipitation from one condensation level and continuously deplete the moisture of ${ }^{18} \mathrm{O}$ in the same direction. There is also evidence for a secondary but minor moisture source in the Arctic Ocean. 


\section{Climate and glagier distribution in the Queen Elizabeth Islands}

The ice caps of the Queen Elizabeth Islands are centered on the higher and more mountainous areas of the eastern islands. However, these ice caps show regional variations in their volume and thickness. For example, Koerner (I977[c]), from echo-sounding work, showed that the thickest ice caps lie on the slopes facing Baffin Bay. However, thickness data over the Queen Elizabeth Islands ice caps is generally meagre. A concept termed the glaciation limit has been used to quantify glacier distribution (e.g. Østrem, 1972) and indeed maps of this index have been published for the east Canadian Arctic by Miller and others (1975). The latter authors also devised an equilibrium-line elevation based on the accumulation/ablation area ratio on the lowest cirque glaciers which should not be confused with Meier's (1962) generally accepted definition of the equilibrium line as the place where accumulation equals ablation. Both the glaciation limit and the equilibrium-line elevation show similar patterns which bear a good relationship with the isohyets in Figure 2. However, neither of the indexes of Miller and others is physically meaningful in itself and it is hard to see what they represent, why they vary, and how they are related to climate. Therefore, one can still only discuss ice distribution and its relationship to climate in a qualitative way. In a general sense the distribution of ice in the Queen Elizabeth Islands does show a good correlation with the accumulation patterns illustrated in Figures 2 and 3. Thus the most continuous ice cover coincides with the area of highest accumulation on the east side of south and central Ellesmere Island and along the east coast of Devon Island. Here the ice caps descend en masse to sea-level which is unique in the Queen Elizabeth Islands and indicates intense glacierization. Conversely, the highest ice edges (ice-cap termini) occur precisely in regions of very low snow accumulation rate on land facing Nansen and Eureka Sounds and Greely Fiord. Koerner (1970) first suggested that ice-cap volumes and distribution in Devon Island was accumulation-controlled and further extended this (Koerner, 1977 [c]) to the high-accumulation area in central Ellesmere Island where radio echo-sounding showed thick ice on the extensive ice caps in the high-accumulation areas facing Baffin Bay and thin ice on the less extensive ice caps on the drier western slopes. This control now seems to be applicable to most of the ice masses of the Queen Elizabeth Islands. However, there are important exceptions. The Arctic Ocean littoral shows a strong ablation control and one should not discount some influence of lower ablation rates in controlling the extent and volume of ice on the slopes facing Baffin Bay. Mass-balance measurements in the latter area have been started by the Polar Continental Shelf Project and should help to quantify this.

\section{SumMARY AND DISGUSSION}

The data have shown a general trend in the eastern Queen Elizabeth Islands from high accumulation which is relatively warm isotopically around the Baffin Bay area to a low, isotopically cold area between Axel Heiberg and north-west Ellesmere Islands. The Arctic Ocean littoral along north-west Ellesmere at least to Meighen Island shows slightly higher accumulation rates and is probably slightly warmer isotopically than the dry interior. Ablation rates do not appear to vary over the Queen Elizabeth Islands regionally except for much lower rates along the north-western Ellesmere coast. However, there is a significant exponential decrease of ablation with increase of elevation. This relationship determines the massbalance/elevation gradient as the data show no dependence of accumulation on elevation. On the other hand, the interaction of the ablation/elevation relationship and the regional variation of accumulation has effected a firn-line elevation (Table IV) which is lowest in the south-east and highest in the Axel Heiberg Island-west Ellesmere Island region.

The exponential gradient of melt with elevation is interesting paleoclimatically as it means that a linear change of climate (in terms of changing heat input in its various forms) will effect 
TABle IV. Firn-Line heights as of MAY/JUNe 1974, Eastern QueEn Elizabeth Islands

\begin{tabular}{cc}
$\begin{array}{c}\text { Traverse } \\
(\text { Fig. I) }\end{array}$ & \multicolumn{1}{c}{$\begin{array}{c}\text { Firn-line elevation } \\
\text { May/fune 1974 } \\
\text { m a.s.l. }\end{array}$} \\
I & 920 \\
$2 \mathrm{a}$ & 630 \\
$2 \mathrm{~b}$ & 470 \\
3 & 830 (firn outlier 200-400) \\
4 & 880 \\
5 & 760 \\
6 & 910 \\
7 & 850 \\
8 & 940 \\
9 & $85^{\circ}$ \\
Io & 1350 \\
I I & 990 \\
N.W. Devon Island & 280 \\
S.E. Devon Island & 800
\end{tabular}

a non-linear change in an ice cap's mass balance with time which in turn will mean non-linear glacier expansion or recession. The non-linearity will be further emphasized when the icearea/elevation distribution is taken into account as well. Thus, Bradley's (1973) linear relationship between equilibrium-line elevation and freezing levels in the Queen Elizabeth Islands can be taken one step further to a non-linear relationship between freezing levels and mass balance. Pursuance of this problem might help to increase our understanding of the advance and retreat of ice caps, both past and present.

\section{Acknowledgements}

Support in the field, under often very difficult conditions, was given by L. Lundgaard, P. Reshitnyk, and P. MacKinnon. Discussions with Dr D. Fisher lead to a clear understanding of the ${ }^{18} \mathrm{O}$ data and I am grateful to Dr F. Müller who allowed the use of some of his unpublished data. I would also like to acknowledge comments of Drs W. S. B. Paterson and B. T. Alt on an early version of the manuscript and a particularly thorough criticism by Dr B. Holmgren on the meteorological aspects of this paper. The ${ }^{18} \mathrm{O}$ analyses were generously undertaken by the Geophysical Isotope Laboratory of Copenhagen under the direction of Dr W. Dansgaard.

MS. received 7 February 1978 and in revised form 18 April 1978

\section{REFERENCES}

Alt, B. T. [1975.] Polar Continental Shelf Project. The energy balance climate of Meighen Ice Cap, N.W.T. [Ottawa], Energy, Mines and Resources Canada. 2 vols.

Ambach, W., and others. 1972. Isotopic oxygen composition of firn, old snow and precipitation in Alpine regions, by W. Ambach, H. Eisner and K. Pessl. Zeitschrift für Gletscherkunde und Glazialgeologie, Bd. 8, Ht. I-2,

p. 1 $25-35$.
Arnold, K. C. I 965 . Aspects of the glaciology of Meighen Island, Northwest Territories, Canada. Journal of Glaciology, Vol. 5, No. 4o, p. 399-4 ro.

Benson, C. S. 1962. Stratigraphic studies in the snow and firn of the Greenland ice sheet. U.S. Snow, Ice and Permafrost Research Establishment. Research Report 70.

Bradley, R. S. 1973. Recent freezing level changes and climatic deterioration in the Canadian Arctic Archipelago. Nature, Vol. 243 , No. 5407, p. 398-400.

Dansgaard, W., and others. 1973. Stable isotope glaciology, by W. Dansgaard, S. J. Johnsen, H. B. Clausen and N. Gundestrup. Meddelelser om Gronland, Bd. 197, Nr. 2.

England, J. 1976. Postglacial isobases and uplift curves from the Canadian and Greenland high Arctic. Arctic and Alpine Research, Vol. 8, No. 1, p. 61 -78 . 
Hattersley-Smith, G. F. 1963. Climatic inferences from firn studies in northern Ellesmere Island. Geografiska Annaler, Vol. 45, Nos. 2-3, p. I39-5I.

Hattersley-Smith, G. F., and Serson, H. 1970. Mass balance of the Ward Hunt ice rise and ice shelf: a 10 year record. Journal of Glaciology, Vol. 9, No. 56, p. 247-52.

Hattersley-Smith, G. F., and Serson, H. 1973. Reconnaissance of a small ice cap near St Patrick Bay, Robeson Channel, northern Ellesmere Island, Canada. Journal of Glaciology, Vol. 12, No. 66, p. 417-21.

Hattersley-Smith, G. F., and others. $196 \mathrm{r}$. The ablation season on Gilman Glacier, northern Ellesmere Island, by G. [F.] Hattersley-Smith, J. R. Lotz and R. B. Sagar. Union Géodésique et Géophysique Internationale. Association Internationale d'Hydrologie Scientifique. Assemblée générale de Helsinki, 25-7-6-8 1960 . Commission des Neiges el Glaces, p. 152-68. (Publication No. 54 de l'Association Internationale d'Hydrologie Scientifique.)

Holmgren, B. $197 \mathrm{I}$. Climate and energy exchange on a sub-polar ice cap in summer. Arctic Institute of North America Devon Island Expedition 1961-1963. Part A. Physical climatology. Meddelanden från Uppsala Universitets Meteorologiska Institution, No. 107.

Koerner, R. M. 1966. Accumulation on the Devon Island ice cap, Northwest Territories, Canada. Journal of Glaciology, Vol. 6, No. 45, p. 383-92.

Koerner, R. M. 1970. The mass balance of the Devon Island ice cap, Northwest Territories, Canada, 1961-66. Fournal of Glaciology, Vol. 9, No. 57, p. 325-36. Koerner, R. M. 1973. The mass balance of the sea ice of the Arctic Ocean. Journal of Glaciology, Vol. 12, No. 65,
p. 173-85. Koerner, R. M. $1977[\mathrm{a}]$. Devon Island ice cap: core stratigraphy and paleoclimate. Science, Vol. 196, No. 4285,
p. 15-18. $^{2}$

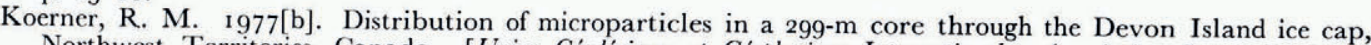
Northwest Territories, Canada. [Union Géodésique et Géophysique Internationale. Association Internationale des Sciences Hydrologiques. Commission des. Neiges et Glaces.] Symposium. Isotopes et impuretés dans les neiges et glaces. Actes du colloque de Grenoble, aout /septembre 1975, p. 371-76. (IAHS-AISH Publication No. 118 .)

Koerner, R. M. 1977 [c]. Ice thickness measurements and their implications with respect to past and present ice volumes in the Canadian high Arctic ice caps. Canadian Journal of Earth Sciences, Vol. 14, No. 12, p. 2697-705.

Koerner, R. M., and Paterson, W. S. B. 1974. Analysis of a core through the Meighen Ice Cap, Arctic Canada, and its paleoclimatic implications. Quaternary Research, Vol. 4, No. 3, p. $253^{-6} 3$.

Koerner, R. M., and Taniguchi, H. 1976 . Artificial radioactivity layers in the Devon Island ice cap, Northwest Territories. Canadian Journal of Earth Sciences, Vol. 1 3, No. 9, p. $125^{1-55}$.

Lorius, C. In press. Antarctica: survey of near surface mean isotope values. (In Robin, G. de Q., ed. Isotopic and temperature profiles in ice sheets. Cambridge, etc., Cambridge University Press.) Meier, M. F. 1962. Proposed definitions for glacier mass budget terms. Fournal of Glaciology, Vol. 4, No. 33,
p. 252-63.

Miller, G. H., and others. 1975. The glaciation level and lowest equilibrium line altitude in the high Canadian Arctic: maps and climatic interpretation, by G. H. Miller, R. S. Bradley and J. T. Andrews. Arctic and Alpine Research, Vol. 7, No. 2, p. 155-68. Mock, S. J. 1967 . Calculated patterns of accumulation on the Greenland ice sheet. Fournal of Glaciology, Vol. 6,
No. 48, p. $795-803$. Mock, S. J. 1968. Snow accumulation studies on the Thule peninsula, Greenland. Fournal of Glaciology, Vol. 7 ,
No. 49, p. 59-76.

Müller, F. 1963. Ablation measurements in 1962. (In Müller, F., and others. Preliminary report 1961-1962, [by] F. Müller [and 18 others]. Axel Heiberg Island Research Reports, McGill University, Montreal. [J̈acobsen-McGill Arctic Research Expedition $1959-1962$ ], p. 37-46.)

Müller, F., and others. 1977 . Isotope measurements and firn stratigraphy on ice caps surrounding the North Water polynya, [by] F. Müller, B. Stauffer and G. Schriber. [Union Géodésique et Géophysique Internationale. Association Internationale des Sciences Hydrologiques. Commission des. Neiges et Glaces.] Symposium. Isotopes et impuretés dans les neiges et glaces. Actes du colloque de Grenoble, aout/septembre 1975, p. 188-96. (IAHS-AISH Publication No. 118.$)$

Ommanney, C. S. L. 1977. Recent work: Canada. Ice, No. 53, p. 2-11. Østrem, G. 1972. Height of the glaciation level in northern British Columbia and southeastern Alaska. Geografiska
Annaler, Vol. 54A, No. 2, p. 76-84.

Paterson, W. S. B. I 1969. The Meighen Ice Cap, Arctic Canada: accumulation, ablation and flow. Journal of Glaciology, Vol. 8, No. 54, p. 341-52. Paterson, W. S. B., and Koerner, R. M. 1974. Radio echo sounding on four ice caps in Arctic Canada. Arctic,
Vol. 27, No. 3, p. 225-33.

Paterson, W. S. B., and others. 1977. An oxygen-isotope climatic record from the Devon Island ice cap, Arctic Canada, by W. S. B. Paterson and R. M. Koerner, D. Fisher, S. J. Johnsen, H. B. Clausen and W. Dansgaard,
P. Bucher and H. Oeschger. Nature, Vol. 266, No. 5602, p. 508-i I.

Schriber, G., and others. $1977 .{ }^{18} \mathrm{O} /{ }^{16} \mathrm{O},{ }^{2} \mathrm{H} /{ }^{1} \mathrm{H}$ and ${ }^{3} \mathrm{H}$ measurements on precipitation and air moisture samples from the North Water area, [by] G. Schriber, B. Stauffer and F. Müller. [Union Géodésique et Géophysique Internationale. Association Internationale des Sciences Hydrologiques. Commission des. Neiges et Glaces.] Symposium. Isotopes et impuretés dans les neiges et glaces. Actes du colloque de Grenoble, aout /septembre 1975, p. 182-87. (IAHSAISH Publication No. 118.

Spector, A. I966. A gravity survey of the Melville Island ice caps. Fournal of Glaciology, Vol. 6, No. 45, p. 393-40o.

Walker, E. R., and Lake, R. A. [ [ ${ }^{\mathrm{r}}$ 975.] Runoff in the Canadian Arctic Archipelago. (In Weller, G., and Bowling, S. A., ed. Climate of the Arctic. [Proceedings of the] 24th Alaska Science Conference, Fairbanks, Alaska, August ${ }_{15}$ to 17, 1973, p. 374-78.) 